\title{
PREVENTING AND FIGHTING AGAINST CLIMATE CHANGE WITH LEGAL MEASURES
}

\begin{abstract}
Gheorghe Durac ${ }^{1}$
1 “Alexandru Ioan Cuza” University, Iasi, e-mail: gheorghe.durac@uaic.ro

Key words: climate change, legal protection, environmental factors, pollution

Abstract. Protecting the environment is an objective that should be of interest to all states, all international bodies, and all citizens, since pollution and its consequences, the ever more pressing climate changes, are problems that can only be solved with actions taken by all the parties involved. This situation requires a more responsible approach towards the actions related to climate change, which makes it necessary to adopt new policies and legal strategies in the field of environmental protection, at a national, European, and international level. An important role is played by the environmental policy, as a form of directing and organising the complex activity of environmental protection, needed to set in place the strategies, methods, and means used in the actions performed nationally and internationally in order to improve the environmental conditions. At present, the complex and global nature of climate change requires an extended and consistent action for cooperation between the states and the international organisations, with the purpose to adopt a rigorous and effective legislation, which would constitute a modern, harmonized, and efficient legal framework, including measures designed, first of all, to lower greenhouse gas emissions.
\end{abstract}

\section{Precedings}

At the beginning of the first century of the third millennium AD, two great dangers menace humankind: terrorism and climate change. Perhaps this is no coincidence. Maybe there is a connection between these two phenomena, even if, at least at first sight, only one has is socio-political in nature. However, in our study we will approach the problems generated by climate change, which are an important challenge for our planet, a true test that humankind needs to pass as successfully and as fast as possible.

A series of severe phenomena have occurred lately: the raise in the annual mean global temperature, which causes, among others, the fast and accentuated melting of the glaciers and the raise of the sea and ocean levels; longer and 
more extended periods of draught, including in continental Europe; more frequent and more aggressive floods. All these require urgent and combined measures from all the world states, international bodies and organisations, and from all the inhabitants of the planet. The main cause of these phenomena is, as scientists claim, greenhouse gas emissions. Their main sources are: burning coal, natural gas and petrol in industries, transport, and in energy production; improper waste storage; extended usage of fluoride industrial gases etc. (Stocker T. F., 2014),

As a result, the European Union has revised its environmental policy, adopting a series of measures for reducing greenhouse gas emissions, of which we mention: allocating consistent funds to research and innovation in the field of discovering and using non-polluting or less polluting energy sources in industry; stimulating and subsidising a more ecological agriculture; implementing new urban planning policies, etc. In this sense, it is important to adopt efficient legal provisions, starting from the international level, continuing with the European Union, and ending with their implementation in the legislation of each member state.

\section{International Legal Provisions concerning Climate Change}

Starting from the provisions of the United Nations Conference on Human environment, Stockholm, June 16, 1972, the main benchmarks in the issue subject to the present analysis are represented by the dispositions of the Resolution no. 44/228 of the General Assembly of December 22, 1989 referring to the United Nations Conference on the environment and development, and to its resolutions no. 43/53 of December 6, 1988, 44/207 of December 22, 1989, 45/212 of December 21, 1990, and 46/169 of December 19, 1991 on world climate protection for present and future generations.

Based on these international regulations, within the Rio de Janeiro Conference, 1992, the United Nations Framework Convention on Climate Change was adopted, which is the main document operating at a world level towards preventing and fighting against climate change. The central objective of the Framework Convention is to set all greenhouse gas concentrations to a level within the normal parameters of the climate system, so as to eliminate any risk or threat that could become a danger for life and health, for food production, or for sustainable economic development. This normative document is a legal framework providing a set of principles based on which the signatory countries engage to adopt and implement a series of measures meant to help achieving the objectives set forth in relation to climate change.

The Conference of the parties, the supreme body of the Framework Convention, has a series of attributions, of which we mention: verifying the 
fulfilment of the obligations taken by the parties and the institutional dispositions resulting from the Convention; stimulating and creating an easy framework for the exchange of information on the adopted measures and their effects; monitoring and coordinating the measures adopted by third-party countries in order to control climate change and its effects (Ţarcă, 2005).

In order to apply in practice the measures taken in order to attain the objectives of the Convention, the parties will follow a series of principles:

- The principle of preventive and precautionary action, according to which the approaches - including the scientific ones - must also be based on forecasts with a certain degree of uncertainty, which must not, however, slow down the rhythm of the actions and measures while waiting for certain proof related to climate change;

- The principle of the efficiency of the policies and measures adopted for a minimum cost level in relation to the benefits;

- The principle of sustainable development, which implies fulfilling the needs of all present and future generations;

- The principle of equity between the states concerning the distribution and adoption of the obligations to reduce greenhouse gases;

- The principle of non-discrimination and solidarity between the states, including in international commercial activities, taking into account the specific situation and needs of developing countries or of countries that are vulnerable to the effects of climate change.

Starting from these principles, the Convention proposes, as a compulsory objective, to set greenhouse gas emissions at a level that would insure eliminating any danger for the climate system, especially the danger of global warming. This objective must be achieved within a relatively short time frame, which would allow the ecosystems to slowly adapt to the inevitable changes, so as not to endanger food production and economical evolution, in line with the principles of sustainable development (Vig, Axelrod, 1999).

The highest level of greenhouse gas emissions occurs in highly industrialised countries and, as such, these states must take responsibility and adopt the required measures to prevent and fight against climate change. In this sense, industrialised countries, besides a series of obligations taken within the Convention, must also support and help, including with financial efforts, the approaches taken by developing countries in the attempt to stop global warming and the negative climate effects. We refer, on the one hand, to assistance and support with advanced technologies that industrialised countries should offer to the states with a lower development potential and, on the other, to the efficiency of the Global Environmental Fund, which implies managing a system of beneficial grants and loans. 
This way, it is possible to allow poor states, in compensation with the reductions adopted by industrialised countries, to have a relatively higher greenhouse gas emissions level, so as to insure their progress, accompanied of course by environmental protection measures. In this context, a transfer of "emission reduction units" is allowed between the states, resulting from projects that contribute to lowering the pollution effects in various fields of economic or social activity (Negruţ, 2008).

Another important international document for this subject matter is the Kyoto Protocol on Climate Change, 1997. The Kyoto Protocol of the United Nations Framework Convention on Climate Change is the answer of the international community to environmental changes. It was adopted, with a consensus, within the third session of the Conference of the Parties (COP3) in December 1997. The Kyoto Protocol was closed as an international environmental agreement, with the purpose to reduce the greenhouse effect. The Protocol was negotiated in December 1997 by 160 countries. One of the main objectives at the closure time was for the signing states to reach, together, by 2012, a level of greenhouse gas emissions $5.2 \%$ lower than the 1990 value. The declines negotiated for each state or group of states were $8 \%$ for the European Union, 7\% for the United States, and 6\% for Japan. At the same time, the Treaty allowed an increase by $8 \%$ of the emissions level for Australia and by $10 \%$ for Iceland. In order to become applicable, the protocol had to be signed by at least 55 countries, which would together produce $55 \%$ of the global carbon dioxide emissions (Grubb, Vrolijk, Brack, 1999).

In October 2004, Russia - responsible for $17.4 \%$ of the greenhouse gas emissions - signed the agreement, which meant that the quota for validating the protocol was achieved. In November 2004, the number of participating countries reached 127, including Canada, China, India, Japan, New Zeeland, Russia, the 25 European Union members, including Romania and Bulgaria (Porcar, 2009). The European Union and its Member States signed the Kyoto Protocol in May 2002, fulfilling the Commission's engagement to apply the protocol before the World Summit on Sustainable Development in Johannesburg, organised between August 24 and September 4, 2002.

In agreement with the provisions of the Kyoto Protocol for the implementation of emission reduction measures, the states benefitted from a flexible and easy system which allowed, among others, performing "emissions trade" activities, as well as the possibility to obtain "emission reduction units" by applying the Joint Implementation mechanism, including by performing and funding environmental projects in other states (Grubb, Vrolijk, Brack, 1999). The Protocol also required the signatory countries to take concrete measures to limit greenhouse gas emissions, to exchange information on climate change 
monitoring data, to cooperate in the field of scientific research for environmental protection, to implement projects for educating and teaching the population in the direction of increasing awareness of the importance of a responsible attitude towards all environmental factors.

Although not all of the defined objectives have been reached, the Kyoto Protocol marked a progress in the effort to lower the negative effects of climate change, as recent scientific data show the need to continue these efforts, requiring stricter measures, especially in order to lower greenhouse gas emissions.

Considering that the first period of commitment under the Kyoto Protocol closed in 2012, a United Nations Conference on climate change was organised at the end of the same year in Doha, with a participation of approximately 200 states. The Doha Amendment, as the document adopted by this Conference is called, defined a new commitment period under the Kyoto Protocol, for the interval 2013-2020, when the greenhouse gas emissions level should drop by $20 \%$ in relation to the 1990 level, as well as an action plan to prepare and close a new global agreement. The UN Conference in Doha also decided to continue working under the Durban Platform (set forth in 2011), preparing the future global agreement in the field of climate change, meant to establish the compulsory commitments for all the Convention Parties. Unfortunately, within the Doha Conference, some unwanted events also occurred, in the sense that Japan, Russian, and New Zeeland decided not to accept the compulsory commitments to lower the emissions in line with the Kyoto Protocol, while one year before, Canada had withdrawn from the Protocol at the Durban Conference - so that the number of states remaining in the international agreement account to only $15 \%$ of the total greenhouse gas emissions.

On December 12, 2015, the $21^{\text {st }}$ Conference of the United Nations Organisations Framework Conference concerning the climate change (COP 21) took place in Paris, with a participation of 195 states, which adopted an Agreement to direct world efforts to limit the raise of the average global temperature to $2^{\circ} \mathrm{C}$. The Paris Agreement wishes to be a complex, multilateral, legal instrument, with compulsory universal applicability in the field of climate change, for the period following the year 2020, with the following fundamental principles: the principle of common but differentiated responsibilities and respective capabilities, the principle of solidarity, and the principle of equity.

The need to adopt the Paris Agreement also came from the fact that the Kyoto Protocol of 1997 was meant exclusively for industrialized countries, whereas the problems linked to global warming concern all the world countries, and the engaged measures must be implemented globally. 
We consider one deficiency of the Agreement to be the lack of clear, concrete medium- and long-term objectives, which can be monitored and achieved. On the other hand, we appreciate the fact that, in the spirit of the principle of solidarity, rich states took the obligation to provide financial support to developing countries, for the latter to resist the impact caused by climate changes threatening humankind (Durac, 2019).

The Agreement came into force on November 4, 2016, one month after the European Union signed the agreement and a few days before the UN Conference on climate change in Marrakech, Morocco. The Agreement, which set forth a long-term global action programme to lower greenhouse gas emissions, was also ratified by three of the most polluting states: the US, China, and India.

For the application and consolidation of the Paris Agreement against global warming, between November 7-18, 2016, in Morocco, Marrakech, took place the $22^{\text {nd }}$ UN Framework Convention Conference of the Parties (COP 22), (Boyd, Schipper, 2002). Almost 200 state delegations were present, including representatives of the civil society and companies, NGOs, scientists, local authorities, local people, unions, and the world mass media, reaching in total over 20,000 participants.

It was convened that the application rules of the Paris climate Agreement should be applied in two years' time, and implementation norms were drawn for the pollution limitation measures, which would allow tracking future progress, with only a general framework defined in 2015.

Among the objectives and propositions of the Marrakech Conference, the most important one was the establishment, by May 2017, of a monitoring system of the initiatives resulted after the Paris Conference (COP 21), based on specific criteria: the international solar alliance, the African Initiative for regenerating energy, Innovation Mission, the Coalition for the carbon price, etc.

Second, we also stress the commitment of the participating countries to take additional actions, which would allow limiting global warming under $2{ }^{\circ} \mathrm{C}$ in relation to the level of 1990, since it was considered that the previously established measures cannot insure that this objective is met.

The discussions and engagements also aimed at the policies, technology, and funding sources needed to reach the objectives agreed upon in the Climate Agreement, estimating that in order to solve climate problems, the (public and private) funds consumed by 2020 amounted to approximately 100 billion dollars. 


\section{European Union's Policy and Legislation concerning Climate} Change

Among the priorities of the political agenda of the European Union, we can mention the issue of climate change, in the sense that constant efforts are made to lower the activities with a risk for the environment, especially polluting and globally warming ones (Oneț, 2017). In order to solve the environmental problems, European Union's environmental policies promote and fight for sustainable development, which implies taking measures to insure lowering greenhouse gas emissions in all activity fields. This objective can only be reached through efficient and rational consumption, based on less polluting energies, using more ecological means of transport with a lower consumption, motivating the economic agents and making them responsible towards the environment, without compromising competitiveness. At the same time, it is necessary to define and implement a new policy for systematisation and urban planning, developing ecological agriculture, and creating a framework favourable for research and innovation (Duţu, 2014).

The current lifestyle of humankind, especially in richer and more economically developed countries, causes extensive climate change, which is a significant danger for the future and existence of life on Earth. Understanding the essential phenomenon affecting world's climate, known as greenhouse effect, requires a new approach, from a different perspective, of the regulating and legal framework meant to insure a better and more effective protection of nature.

A reference legal document within the European Union is the Council's Directive 96/62/CE of September 27, 1996 on the evaluation and management of air quality. Analysing air quality policies showed that actions in this direction should focus on insuring compliance, by the end of 2020 the latest, with the applicable standards in air quality and on using a revised directive concerning national emission ceilings, with the purpose of lowering polluting emissions by 2030. The respective emission limits will result in lowering the concentrations of harmful substances all over Europe, generating major benefits for public health and ecosystems.

The purpose of this Directive is to insure that within the shortest timeframe possible, all concentrations will follow a descending trend, under the benchmarks set by the World Health Organisation (WHO).

Based on the principles of European social law, European Union's institutions show constant concern with environmental protection, and in this sense they fight for and take measures to establish and raise the life quality standards, defining efficient public policies for social health and protection. At the same time, this approach must insure an appropriate dynamics for economic 
growth, which would trigger the progress and, to an equal extent, the protection of environmental factors, in the present alarming context generated by crossborder pollution and climate change (Teodoroiu, 2009).

The provisions of the Gothenburg Protocol of December 1, 1999, referring to lowering acidification, eutrophication, and tropospheric ozone level, were adopted by the European Union with Directive no. 2001/81/CE concerning the national emission ceilings for certain atmospheric pollutants (called the NEC Directive). The objectives of these normative acts were to control and reduce sulphur dioxide, nitrogen oxides, ammonia and volatile organic compounds emissions, which can have negative effects on human health and natural ecosystems (terrestrial and aquatic), on agricultural materials and crops because of the acidification and eutrophication effect, or forming tropospheric ozone, as well as to insure, on the long run, that the air deposits and concentrations of pollutants having an acidification or eutrophication effect, or generating tropospheric ozone, do not exceed the critical charges and levels set for the sensitive environmental elements.

Another legal document worth mentioning is Directive 2003/35/CE of the European Parliament and Council of May 26, 2003, instituting the public's participation in designing certain environmental plans and programmes. The main objective of this directive is to elicit the public's participation following certain environmental plans and programmes. To this purpose, the member states must identify the appropriate public to participate in this approach, including the relevant non-governmental organisations that meet the requirements of internal legislation, as well as those promoting environmental protection.

According to the provisions of this Directive, the member states establish the norms for the public's participation in drawing specific environmental plans and programmes, so as to facilitate effective information, preparation, and participation. The norms must foresee reasonable deadlines that would allow enough time for each stage of the public's involvement in the respective actions.

The fact that hundreds of thousands of Europeans die each year from respiratory and cardiovascular diseases caused by gas emissions and atmospheric particles triggered the adoption of another normative act, which imposed a stricter limit for air polluting factors. This is (EU) Directive 2016/2284 of the European Parliament and Council of December14, 2016, on lowering the national emissions of certain atmospheric pollutants, modifying Directive 2003/35/CE and cancelling Directive 2001/81/CE.

This European legal document set forth the national objectives for lowering emissions of five air-polluting factors until 2030, in relation to the reference year 2005. The polluting factors concerned are: nitrogen oxides (NOx), coming 
from the usage of cars, trucks, and electric heaters; non-methane based volatile organic compounds (NMVOCs), coming from surface coverage with various substances, paints, using solvents, from the chemical and food industries; ammonia (NH3), resulted from agricultural activities: usage of fertilisers and animal farming; sulphur dioxide (SO2), mainly resulted from energy-generating activities; very small particles (PM2.5) coming from burning coal and wood, road transport, factories, and electric heaters.

This action reiterates the European Union's effort to identify and find solutions to the source control legislation, which does not work, as we can see in the difference between real-life emissions and NOx emissions in test conditions for diesel euro 6 cars.

In agreement with the provisions of the Paris Agreement on climate change, in December 2019, the European Council consecrated the objective for the EU to become climatically neutral by 2050 , stressing the fact that the transition towards climate neutrality will generate significant opportunities for markets, jobs, and technological advances, generally for economic growth, in parallel with visible results in the field of environmental protection.

In order to meet the bold objective of becoming the first climatically neutral continent by 2050, the European Commission drew and presented, in December 2019, the European green deal, meant to insure the protection and preservation of Europe's natural environment, through investments in lastgeneration research and innovation, though an ambitious reduction of emissions, and other similar actions. In this context, the European Commission adopted, at the beginning of March this year, a legal proposition aiming to each zero-emissions of greenhouse gases by 2050 , a project that needs to be approved by the European Parliament and Council in order for it to become European law.

With regards to Romania's policies concerning the compliance with the adopted international regulations, laid down in the United Nations' Framework Convention on Climate Change, the Kyoto Protocol, European union's Directives in this matter, as well as the national priorities in the field, they can all be found in the first National Strategy on climate change, adopted in July 2005.

At the same time, this Strategy mentions the environmental and economic benefits for our country, through its involvement in implementing the flexible mechanisms set forth by the Kyoto Protocol: common implementation, international sale of emissions, and the Clean Development Mechanism (Lupan, 2008).

The central objective of this Strategy focuses, first of all, on insuring the fulfilment of the commitments that Romania agreed upon following the United 
Nations' Framework Convention and the Kyoto Protocol, and, at the same time, of the obligations on climate change, agreed upon through its joining the European Union. Second, the aim is to draw and implement Romania's voluntary objectives and actions concerning its adaptation to the impact of climate change, lowering the concentration of carbon in economy, and using the flexible mechanisms imposed by the Kyoto Protocol, for raising the competitiveness of Romanian economy (Marinescu, 2010).

The national policy for reducing greenhouse gas emissions aims, on the one hand, to insure that the economic operators participate in applying the emission certificates sale programme and, on the other, to adopt sectorial policies and measures that help the national-wide emissions corresponding to this sectors follow the linear trend of the emission limits set by the application of Decision no. 406/2009/CE on the member states' effort to lower greenhouse gas emissions.

We can notice that many states make strong efforts to take action on climate change, of course, in relation to specific economic, social, and institutional factors, which implies the need to negotiate coordinated strategies at a European and international level, to overcome any possible issues that may occur in this approach (Grubb, Vrolijk, Brack, 1999).

\section{Conclusions}

Climate change is now considered the main threat to global stability and safety. At the same time, studies show that the cost estimations related to climate change could reach approximately $14 \%$ of the mean consumption, per inhabitant worldwide. In this context, approaches are attempted and continuously made to integrate and generalise climate and the existing trends in environmental protection at a world level to be included in all taken decisions. Thus, with the occurrence, in Western society, of the trends to improve life conditions and to eliminate pollution, measures must be taken everywhere, sometimes quire restrictive in nature.

In this sense, the legal framework must be improved for a rigorous application of the provisions of the United Nations Convention on climate change, of the Kyoto Protocol, and of the Paris Agreement, through drawing and adopting normative acts specific to the climate change issue and, at the same time, through a correlation with the related legislation, specific to energy, transport, agriculture, etc.

An important benchmark in fighting and preventing the effects of climate change is represented by the European Union's programmes and policies in the field, demanding actions to restructure the current production and consumption 
models based on improving eco-efficiency and technological innovation, so that the actions to prevent and fight against the negative consequences of climate change do not result in slowing down economic growth and lowering life standards.

\section{Bibliography}

Boyd Emily, Schipper Ema Lisa (2002), The Marrakech Accord -At the Crossroad to Ratification: Seventh Conference of the Parties to the United Nations Framework Convention on Climate Change, The Journal of Environment \& Development 11(2):184-190, https://doi.org/10.1177/10796502011002006.

Durac G. (2019), The Legal Protection of Environmental Factors - A Premise for Sustainable Development, to the International Business Information Management Conference (33th IBIMA), 10-11 april 2019, Granada, Spania.

Duţu M. (2014), Dreptul mediului, $4^{\text {th }}$ edition, CH Beck Publishing House, p. 56.

Grubb M., Vrolijk C., Brack D. (1999), The Kyoto Protocol - A Guide and Assessment, The Royal Institute of International Affairs, p.116.

Lupan E. (2008), Tratat de dreptul protecţiei mediului, C.H Beck Publishing House, Bucharest, p. 125.

Marinescu D. (2010), Tratat de dreptul mediului, $4^{\text {th }}$ edition, revised and completed, Editura Universul Juridic, Bucharest, p. 134.

Negruț V. (2008), Dreptul mediului, Editura Fundaţiei Academice "Danubius", Galaţi, p. 112.

Oneț C. (2017), Dreptul mediului, , Universul Juridic Publishing House, Bucharest, p. 268.

Porcar D.D. (2009), Schimbări climatice şi protecţia atmosferei, U. T. Press Publishing House, Cluj-Napoca, 2009, p. 67.

Stocker T. F. (2014), Climate Change 2013, The Physical Science Basis, Working Group I, Contribution to the Fifth Assessment Report of the Intergovernmental Panel on Climate Change, Working Group I Technical Support Unit, Cambridge University Press, 10.1017/CBO9781107415324

Teodoroiu S. M. (2009), Dreptul Mediului şi dezvoltării durabile. Curs Universitar, Editura Universul Juridic, Bucharest, p. 269.

Țarcă Șt. (2005), Dreptul Mediului. Curs Universitar, Lumina Lex Publishing House, Bucharest, p. 192.

Vig N. J., Axelrod R. S. (1999), The Global Environment- Institutions, Law and Policy, Earthscan Publications Ltd, p. 210.

A/CONF.48/14/Rev.1 (1972), Stockholm Declaration on the Human Environment, in Report of the United Nations Conference on the Human Environment, UN Doc.A/CONF.48/14, at 2 and Corr.1, Stockholm (https://digitallibrary.un.org/record/523249). 
United Nations (1992), United Nations Framework convention on climate change, United nations, 1992, FCCC/INFORMAL/84 GE.05-62220 (E) 200705, https://unfccc.int/resource/docs/convkp/conveng.pdf

United Nations (1998), Kyoto Protocol to the United Nations Framework Convention on Climate Change, United Nations, 1998 , https://unfccc.int/resource/docs/convkp/kpeng.pdf

The European Parliament (2009), Decision No 406/2009/EC of the European Parliament and of the Council of 23 April 2009 on the effort of Member States to reduce their greenhouse gas emissions to meet the Community's greenhouse gas emission reduction commitments up to 2020, Brussels, http://data.europa.eu/eli/dec/2009/406/oj

United Nations (2015), Paris Agreement, United Nations, https://unfccc.int/sites/default/files/english_paris_agreement.pdf

The European Parliament (2016), Directive (EU) 2016/2284 of the European Parliament and of the Council, 14 December, on the reduction of national emissions of certain atmospheric pollutants, amending Directive 2003/35/EC and repealing Directive 2001/81/EC, European Journal of UE, https://eurlex.europa.eu/eli/dir/2016/2284/oj

European Commission (2019), The European Green Deal, European Commission, $\operatorname{COM}(2019)$ 640, Brussels,

https://ec.europa.eu/info/sites/info/files/european-green-deal-communication_en.pdf

(C) 2020 by the authors. Licensee UAIC, Iasi, Romania. This article is an open access article distributed under the terms and conditions of the Creative Commons Attribution (CC BY-NC-ND) license (https://creativecommons.org/licenses/by-nc-nd/4.0). 